УДК 378.147:004.032.6:37.011.3-051:78

Гаврілова Людмила Гаврилівна

кандидат мистецтвознавства, доцент, докторант

Інститут інформатики НПУ імені М. Драгоманова, м. Київ, Україна

lusjamuz@mail.ru

\title{
ПРИНЦИПИ ФОРМУВАННЯ ПРОФЕСІЙНОЇ КОМПЕТЕНТНОСТІ МАЙБУТНІХ УЧИТЕЛІВ МУЗИКИ ЗАСОБАМИ МУЛЬТИМЕДІЙНИХ ТЕХНОЛОГІЙ
}

\begin{abstract}
Анотація. Стаття присвячена актуальній проблемі сучасної вищої мистецької освіти використанню комп'ютерних, зокрема мультимедійних, технологій у професійній підготовці майбутніх учителів. Авторка розглядає принципи формування професійної компетентності майбутніх учителів музики засобами мультимедійних технологій: принцип інформатизації навчання; принцип наочності, реалізований засобами мультимедія; принцип оптимального вибору засобів навчання; принцип інтеграції традиційних методик музичного навчання й інноваційних мультимедійних технологій; принцип цілеспрямованої взаємодії і художньо-творчого спілкування педагога зі студентами; принцип активізації музичнотворчої діяльності, спонукання до творчого самовираження. Дотримання цих принципів забезпечує професійний розвиток майбутніх учителів музики засобами мультимедійних технологій.
\end{abstract}

Ключові слова: професійна компетентність; мультимедійні технології; майбутні вчителі музики; принципи навчання.

\section{1. ВСТУП}

Постановка проблеми. Однією 3 визначальних тенденцій сучасної освіти $\epsilon$ інформатизація, яка відбувається в усіх освітніх ланках, від дошкільної до вищої. Інформатизація навчального процесу, комп'ютеризація освітніх закладів, розробка електронних освітніх ресурсів, інші тенденції освіти, пов'язані 3 активним упровадженням інформаційно-комунікаційних технологій, засвідчують утворення нового освітнього феномену, що визначається науковцями як інформаційнокомунікаційне педагогічне середовище (ІКПС) (О. Співаковський, Л. Петухова, В. Коткова), інформаційно-освітнє середовище (IOC) (Л. Панченко), єдиний інформаційний освітній простір (О. Могилев, Т. Яшина) тощо.

Процеси інформатизації наразі торкнулися й мистецької освіти, зокрема іiі музично-педагогічної галузі. Учені (А. Бондаренко, Л. Варнавська, І. Гайденко, I. Горбунова， М. Дядченко, Л. Заря, І. Красильников, О. Красноскулов, В. Луценко, Н. Новікова, С. Полозов, О. Рибніков, Г. Тараєва, А. Харуто, О. Чайковська та ін.) наголошують на необхідності введення нових технологій у навчання музичних дисциплін, що оптимізує навчальний процес, робить його високохудожнішим i високотехнологічним. Науковці доводять підвищення ефективності музичнопедагогічного процесу завдяки застосуванню комп'ютерних навчаючих технологій.

Комп'ютеризація музичної освіти - процес, який відбувається у багатьох країнах світу; в останні десятиліття сформувався самостійний напрямок - музичнокомп'ютерні технології (МКТ) як сучасна освітня програма, пов'язана 3 навчанням основ електронної та комп'ютерної музики, а також створенням і практичним застосуванням нових мультимедійних навчальних засобів з музичного мистецтва.

В останні роки у вітчизняній педагогіці з'явилися дослідження, пов'язані iз залученням інформаційно-комунікаційних технологій до професійної музично- 
педагогічної освіти, з формуванням тих чи інших сторін професійної компетентності майбутніх учителів музики з використанням комп'ютерних засобів (А. Бондаренко, О. Бордюк, Л. Варнавська, Ю. Дворник, Л. Заря, А. Камеріс, В. Луценко, О. Приселков, О. Рибніков та ін.), проте вони не надають системного уявлення про роль ІКТ у цілісному професійному розвитку музиканта-педагога, висвітлюючи його окремі аспекти, до того ж питання професійної компетентності майбутнього вчителя музики, що наразі $\epsilon$ надзвичайно актуальними, розглядаються побіжно, перевага надається проблемам формування пізнавальної самостійності вчителів, готовності до використання комп'ютерних засобів, визначенню методичних засад використання IКТ у підготовці музикантів тощо.

Об'єктивна потреба й соціальна значущість якісної професійної підготовки майбутніх учителів музики, що відповідають вимогам сучасного інформаційного суспільства й вільно орієнтуються в інформаційному освітньому середовищі, відсутність системності у використанні комп'ютерних технологій у вищій музичнопедагогічній освіті зумовили розроблення й упровадження у практику цілісної системи формування професійної компетентності майбутніх учителів музики засобами мультимедійних технологій. Розроблена нами система грунтується на певних основоположних принципах, що визначають зміст, організаційні форми та методи навчального процесу.

Аналіз досліджень і публікацій. Виокремлюючи певні принципи як визначальні системотворчі чинники, ми виходили із загальнофілософського тлумачення: принцип (від лат. principium - початок, основа) - 1) першооснова, те, що лежить в основі певної сукупності фактів, теорій, науки; 2) внутрішні переконання людини, ті практичні, моральні й теоретичні засади, якими вона керується в житті, у різноманітних сферах діяльності [1]. Важливими виявилися й загально-педагогічні погляди на принципи навчання як основоположні ідеї, що пронизують собою всю систему науково-дидактичного знання i субординують його (I. Зайченко [2]). Сучасна педагогіка (С. Гончаренко, І. Зязюн, О. Пехота, Г. Пустовіт та багато інших науковців) висуває систему принципів залежно від сутності навчання й виховання, принципи віддзеркалюють освітні цілі й закономірності процесу навчання. Базовими є принцип урахування індивідуальних особливостей учнів, їхніх вікових відмінностей та закономірностей розвитку; принцип цілеспрямованості і цілісності у навчанні; науковості, доступності та системності та зв’язку навчання 3 життям; принцип контролю і корекції знань учнів; принцип систематичності і послідовності; принцип поєднання освіти і самоосвіти, розвитку і саморозвитку, виховання і самовиховання. Ці принципи складають систему принципів навчання, адже всі вони описують цілісне, системне педагогічне явище, яким є процес навчання.

Слід зауважити, що концептуальну основу мистецької, зокрема музичної, освіти складає система принципів мистецького навчання, визначених і схарактеризованих Г. Падалкою [3]. Науковець виокремлює найголовніші принципи навчання мистецтва (цілісності, культуровідповідності, естетичної спрямованості, індивідуалізації, рефлексії), які «містять в собі цілепокладальні орієнтири поліпшення мистецької освіти, удосконалення їі змісту і методичних засад» [3, с. 149].

Аналіз наукових досліджень у галузі музичної педагогіки дозволяє стверджувати, що навчання музики також грунтується на загальнодидактичних принципах, крім того ефективність навчального процесу й реалізацію мети музичного виховання забезпечують специфічні принципи, які відтворюють специфіку музики як виду мистецтва, а також специфіку музичної діяльності. Ціла низка музикантів-педагогів (Б. Асаф’єв, В. Шацька, О. Апраксіна, Д. Кабалевський та ін.), узагальнюючи власний 
педагогічний досвід, намагалися сформулювати принципові для музичної педагогіки положення, серед яких:

- ознайомлення учнів 3 кращими зразками музичної творчості, формування емоційного відгуку на музику разом із розвитком музичних здібностей (В. Шацька);

- єдність виконавської і музично-пізнавальної діяльності (Н. Гродзенська);

- спрямованість музичних занять на духовний розвиток особистості, формування музичної грамотності як здатності сприймати музику, опора на «трьох китів» як реалізація принципу зв'язку навчання з життям (Д. Кабалевський).

Низку принципів музичної освіти виокремив Е. Абдуллін, він тлумачить їх як «вихідні положення, що розкривають сутність мети й завдань музичної освіти» [4, с. 62] i виділяе групи принципів різної спрямованості: гуманістично-естетичної (виявлення зв'язків музичного мистецтва 3 духовним життям; вивчення музичного мистецтва в загальноісторичному контексті й у взаємозв'язку з іншими мистецтвами; орієнтація на шедеври музичної творчості та ін.), музикознавчої (вивчення музичного мистецтва в опорі на єдність народної, академічної і духовної музики; опора на інтонаційний, стильовий і жанровий підходи), музично-психологічної (спрямованість музичного навчання на розвиток музичних здібностей учнів, оволодіння ними різними видами музичної діяльності; реалізація арттерапевтичних можливостей музики тощо), педагогічної (єдність музичного навчання, виховання і розвитку; дотримання загальнопедагогічних принципів науковості, систематичності, послідовності в організації музичних занять та ін.) [4, с. 62-63].

Наведемо також принципи навчання музики, сформульовані російськими педагогами В. Усачевою, Л. Школяр, В. Школяр - авторами однієї з чинних навчальних програм з музичного мистецтва:

- викладання музики в школі як живого образного мистецтва;

- проблематизація змісту музичної освіти (піднесення дитини до філософськоестетичної сутності мистецтва);

- занурення у природу мистецтва і його закономірності;

- моделювання художньо-творчого процесу;

- діяльнісне засвоєння мистецтва [5].

Заслуговують на увагу і концепція музичного виховання, розроблена Б. Алієвим, яка спирається на принципи зв'язку музичних занять 3 життям, єдності емоційного і свідомого, художнього і технічного у музичному навчанні, а також основні загальнодидактичні принципи [6].

Ретельно проаналізовані принципи музичного навчання у грунтовному дослідженні теорії і методики музичної освіти О.Р Науковець розглядає закономірності, які лежать в основі музично-освітнього процесу й визначають його успішність, і знаходить принципи, які відображують ці закономірності, відзначаючи відносно стійкі зв'язки, характерні для музичної освіти [7].

Отже, аналізуючи провідні науково-педагогічні розробки 3 точки зору основоположних принципів навчання, поглиблюючи методологію нашого дослідження, ми виділили низку принципів, які розкривають підходи до професійного розвитку майбутніх учителів музики, визначають зміст, організаційні форми і методи 3 урахуванням мети й закономірностей мистецької освіти.

Мета статті - проаналізувати принципи формування професійної компетентності майбутніх учителів музики засобами мультимедійних технологій, дотримання яких забезпечує ефективність професійної підготовки майбутніх педагогівмузикантів. 


\section{2. МЕТОДИ ДОСЛІДЖЕННЯ}

Під час дослідження використовувались такі методи: аналіз наукових і навчальнометодичних джерел 3 проблеми визначення основоположних закономірностей $\mathrm{i}$ принципів упровадження новітніх інформаційних технологій у систему підготовки майбутніх учителів; вивчення й узагальнення передового досвіду організації застосування мультимедійних технологій у практиці мистецької, зокрема музичної, освіти.

\section{3. РЕЗУЛЬТАТИ ДОСЛІДЖЕННЯ}

На нашу думку, формування професійної компетентності майбутніх учителів музики засобами мультимедійних технологій має забезпечуватися дотриманням таких принципів навчання, як-от:

- принцип інформатизації навчання;

- принцип наочності, реалізованої засобами мультимедія;

- принцип оптимального вибору засобів навчання;

- принцип інтеграції традиційних методик музичного навчання й інноваційних мультимедійних технологій;

- принцип цілеспрямованої взаємодії і художньо-творчого спілкування педагога зі студентами;

- принцип активізації музично-творчої діяльності, спонукання до творчого самовираження.

Слід зауважити, що визначені принципи необхідно застосовувати комплексно, що сприятиме підвищенню ефективності результатів якості освіти. Названі вище принципи грунтуються на загальних закономірностях музично-педагогічної освіти, відображають вимоги сучасного інформаційного суспільства до професійної компетентності майбутніх учителів музики, визначають основні напрями навчальної діяльності студентів у процесі професійного розвитку.

Розглянемо докладніше дію названих принципів як методологічних орієнтирів $\mathrm{i}$ чинників формування професійної компетентності майбутніх учителів музики засобами мультимедійних технологій.

\section{1. Принцип інформатизації навчання}

Принцип спрямований на розв'язання ключового завдання сучасної системи освіти - підвищення якості освіти на основі використання новітніх інформаційнокомунікаційних технологій. Наразі цей принцип набуває особливої значущості в умовах стрімкої інформатизації освітнього процесу, що стає визначальною рисою розвитку освіти в інформаційному суспільстві.

Принцип інформатизації передбачає формування в освітньому процесі вмінь і навичок роботи 3 електронними засобами пошуку, опрацювання $\mathrm{i}$ передавання інформації, задоволення інформаційних потреб, розвиток творчого й інтелектуального потенціалу учнів, використання інформаційних ресурсів у подальшій професійній діяльності та повсякденному житті. Дотримання принципу інформатизації дозволяє забезпечити підготовку суб'єктів навчального процесу до життєдіяльності в умовах інформаційного суспільства, коли понад 50 \% робочих місць передбачає використання комп'ютерів і мережі Інтернет, а діяльність учителя - справжнього професіонала - 
стає практично неможливою без активного залучення інформаційно-комунікаційних технологій.

Принцип інформатизації надає можливості інтенсифікувати навчальний процес на основі структурно-логічного пред'явлення навчального матеріалу, мультимедійної форми його подання, урахування соціальних i культурних відмінностей, індивідуальних стилів і темпів навчання кожного студента (учня). Завважимо, що поступова перебудова навчального процесу в умовах інформатизації освіти, широке розповсюдження електронних засобів навчання призвели до формування самостійного розділу педагогічної науки - е-педагогіки ${ }^{1}$ (електронної педагогіки, e-Learning), яку характеризують власні принципи, понятійний апарат, форми і методи навчання, нові види навчальних занять тощо.

Науковці, які досліджують становлення інформаційно-технологічної парадигми освіти в новому інформаційному суспільстві, доводять, що у відкритому світовому освітньому просторі інформаційного суспільства головною цінністю стає особистість як утримувач основного капіталу - знання (В. Биков, М. Жалдак, Ю. Машбиць, Д. Прокудін, І. Роберт та ін.).

Отже, дотримання принципу інформатизації веде до утворення у вищому навчальному закладі специфічного інформаційно-комунікаційного педагогічного середовища як «сукупності знанієвих, технологічних і ментальних сутностей, які в синхронній інтеграції забезпечують якісне оволодіння системою відповідних знань» (Л. Петухова [9]), функціонування якого принципово важливо під час реалізації системи формування професійної компетентності майбутніх учителів музики засобами мультимедійних технологій.

\section{2. Принцип наочності}

Загальнодидактичний принцип наочності, сформульований Я. Коменським та описаний його послідовниками Й. Песталоцці, А. Дістервегом, класиками науковопедагогічної думки радянських часів, сучасними науковцями, в умовах застосування в навчальному процесі інформаційно-комунікаційних технологій можна назвати принципом мультимедія.

Аналізуючи дію принципу наочності в музичній освіті, О. Олексюк [10] підкреслює його особливу значущість, пояснюючи свою думку використанням у різних видах музичної діяльності наочності різних типів: виконавської (демонстрація музичних фрагментів або ілюстрування теоретичних положень звучанням музики) та зображальної (репродукцій картин, творів інших видів мистецтв тощо). Уведення засобів мультимедія дозволяє об'єднати різні типи наочності в одному ресурсі.

Усі можливі види наочності можуть бути об'єднані в одному мультимедійному засобі: будь-які статичні зображення, включаючи малюнки, фотографії, репродукції творів мистецтва, нотні тексти та ін.; будь-які звуки, серед яких можуть бути і звуки оточуючого світу, і звуки музики; анімація, мультиплікація, відеозапис будь-яких явищ природи, людського життя й творів мистецтва, тобто будь-які динамічні процеси - усе це стає доступним для використання у навчальному процесі завдяки технології мультимедія як такої, що дозволяє гнучко керувати потоками різноманітних інформаційних ресурсів, об'єднуючи їх в інтерактивному режимі. Окремий різновид мультимедійної наочності - віртуальна реальність, яка занурює користувача в уявний світ, створює ілюзію присутності в реальному часі в стереоскопічно представленому штучному світі.

\footnotetext{
${ }^{1}$ Термін уведений у науковий обіг О. Андрєєвим [7].
} 
Наукою доведено, що засоби наочності впливають на органи відчуттів, що сприяє підвищенню ефективності навчального процесу (встановлюються зв' язки між науковим знанням й життєдіяльністю, між теорією і практикою; формується інтерес до набуття знань, мотивація навчання тощо). Наочність засобів мультимедія відрізняється підсиленою дією на відчуття людини, проектування й розробка мультимедійних засобів ведуться так, щоб кожен виразний аспект цієї продукції був результатом максимального впливу на відчуття користувачів.

Використання засобів мультимедія у навчальному процесі вимагає дотримання загальнодидактичних правил принципу наочності, серед яких чітке визначення мети використання засобів наочності; усунення зайвого, щоб не викликати додаткових асоціацій; активне залучення до роботи із засобами наочності суб' єктів учіння, що реалізується завдяки інтерактивній природі мультимедійних технологій; застосування наочності на всіх етапах навчального процесу; урахування психологічних закономірностей сприймання тощо.

Отже, дотримання закономірностей принципу наочності забезпечує ефективне використання мультимедійних навчальних засобів у музичному навчанні, що передусім стосується МНЗ з музично-історичних дисциплін, оскільки саме вони потребують залучення майже всіх різновидів мультимедія-даних (нотних i фотоматеріалів, репродукцій творів образотворчого мистецтва, аудіо- та відео-фрагментів виконання музичних творів різних жанрів, творів кіномистецтва, театру, мультиплікації тощо).

\section{3. Принцип оптимального вибору засобів навчання}

Педагогічною наукою доведено, що засоби навчання як матеріальні або ідеальні об'єкти, «розміщені» між учителем і учнем і використані для засвоєння знань, формування досвіду пізнавальної і практичної діяльності (I. Зайченко [2]), мають суттєвий вплив на якість знань, особистісний розвиток і професійне зростання учнів. У сучасній системі освіти все більшого значення набувають електронні й мультимедійні навчальні засоби - електронні підручники і посібники, навчальні комп'ютерні програми, електронні освітні ресурси (ЕОР), педагогічні програмні засоби (ППЗ), мультимедійні електронні видання, програмні засоби навчального призначення, цифрові освітні ресурси (ЦОР) тощо. Зорієнтуватися серед нових навчальних видань не завжди просто, тож проблема вибору засобів навчання $\epsilon$ надзвичайно актуальною.

Дотримання принципу оптимального вибору засобів навчання означає, що майбутній учитель музики, готуючись до професійної діяльності, має ознайомитися 3 існуючими навчальними засобами (як друкованими, так і електронними), уміти проаналізувати їх зміст і структуру з точки зору відповідності навчальній програмі, вмісту інформації, урахування вікових психолого-педагогічних закономірностей учнів тощо. Учитель має знати і численні вимоги, що їх висувають до сучасних навчальних, зокрема комп'ютерних, навчальних засобів: психолого-педагогічні, методичні, здоров'язбережувальні вимоги, дизайн-ергономічні чинники тощо. Попри це, високий рівень професійної компетентності майбутнього вчителя передбачає вміння створювати навчальні засоби власноруч — цю можливість йому надають мультимедійні технології.

Моделюючи власну систему формування професійної компетентності майбутніх учителів музики засобами мультимедійних технологій, ми керувалися принципом оптимального вибору засобів навчання, оскільки намагалися заповнити вакуум, існуючий у засобах навчання музичного мистецтва, зокрема музично-історичних дисциплін. Щоб підняти на вищий рівень викладання історії музичного мистецтва для майбутніх музикантів-педагогів, вплинути на їхнє професійне зростання, ми розробили мультимедійні навчальні засоби: мультимедійний підручник 3 історії музичного 
мистецтва й електронний навчальний посібник «Українська духовна музика» (навчальні засоби можна знайти на сайті автора статті за адресою: http://multimusic.com.ua/). До того ж була проаналізована значна кількість (близько 100) існуючих вітчизняних i зарубіжних електронних освітніх ресурсів: навчальних комп'ютерних програм, навчально-ігрових дитячих видань, тренажерів музичного слуху, інформаційно-довідкових електронних джерел, Інтернет-видань тощо. Серед них були виокремлені навчальні засоби, які на нашу думку, доцільно використовувати у професійній підготовці майбутніх учителів музики.

\section{4. Принцип інтеграції традиційних методик музичного навчання й інноваційних мультимедійних технологій}

Принцип має концептуальне значення у впровадженні системи формування професійної компетентності майбутніх учителів музики засобами мультимедійних технологій, оскільки він зорієнтовує на поєднання у музичній освіті «традиційного» і «інноваційного» підходів. Традиційне у музичному навчанні — це відпрацьована віками система індивідуальних занять 3 навчання гри на музичному інструменті, диригування, співу; залучення майбутніх учителів до музикування в оркестрі та співу у хоровому колективі; обов' язкове слухання музичної класики, аналіз музичних творів як складові професійного зростання музиканта-педагога. Інноваційні підходи пов'язані із залученням нових технологій (особистісно-орієнтованих, інформаційнокомунікаційних, дистанційного навчання, технологій професійного розвитку на акмеологічних засадах тощо). Традиційна система музичного навчання, зважаючи на принципові зміни в сучасному освітньому середовищі, уже не задовольняє суспільні потреби, проте повністю реформувати й трансформувати цю систему не має сенсу, оскільки певні методи і форми музичної освіти не мають альтернативи. Оптимальних результатів можна досягти, дотримуючись принципу інтеграції традиційних методик музичного навчання й інноваційних мультимедійних технологій: зберігаючи ефективні традиційні форми музично-педагогічної освіти, можна перетворити майбутніх учителів музики в активних суб'єктів процесу навчання, які засвоюють і генерують знання, отримані 3 різноманітних джерел; інформаційна комунікація стає багатоканальною системою, яка забезпечує інформаційну взаємодію між викладачем і студентами; діяльність студентів набуває яскраво вираженого творчого характеру.

Інтегрування у професійній підготовці майбутніх учителів музики традиційних методик та інноваційних мультимедійних технологій стимулює до пошуку нових форм і методів музичного навчання. Цей процес пов'язаний не лише із залученням нового, але й 3 оновленням традиційного: мультимедійні технології надають можливості суттєво оновити давно відомі підходи до професійної підготовки вчителя музики.

\section{5. Принцип цілеспрямованої взасмодії і художньо-творчого спілкування педагога зі студентами}

Реалізація цього принципу у процесі формування професійної компетентності майбутніх учителів музики набуває нових рис завдяки новому рівню інформаційної комунікації, яку забезпечують мультимедійні технології. У цьому принципі знайшла відображення одна 3 ключових закономірностей музичного навчання: досягнення мети музичної освіти можливе лише за цілеспрямованої взаємодії вчителя й учнів.

Науковці (Г. Падалка, О. Рудницька, О. Щолокова та ін.) відзначають, що наразі в системі музичної освіти (як і в мистецькій освіті загалом) відбуваються докорінні зміни у стилі спілкування: новий тип спілкування — суб'єкт-суб'єктний — вимагає нового 
відношення до особистості студента, у якому викладач знаходить унікальну особистість, що не лише засвоює знання й відпрацьовує навички, а продукує естетичні цінності, активно займається творчістю, має власну думку тощо.

Попри це, слід вказати, що застосування у професійній підготовці майбутніх учителів музики засобів мультимедійних технологій значно розширює можливості навчальної комунікації: мультимедія стають одним із засобів невербальної комунікації, яку науковці визначають як вид спілкування, коли використовуються не слова, а інші засоби (міміка, жести, інтонації тощо) [11]. Завдяки технології мультимедія стає можливим комплексне залучення до музичного навчання звукових (музичних) i візуальних образів, що значно доповнює арсенал засобів комунікації.

Сучасні інформаційно-комунікаційні технології також відкривають простір для дистанційного спілкування, основні його види - асинхронне (електронне листування, список розсилань, форум) і синхронне (чат) спілкування - активно використовуються в процесі формування професійної компетентності майбутніх учителів музики. Дистанційне спілкування автора дослідження зі студентами - майбутніми педагогамимузикантами - здійснюється на сайті «Мультимедійні технології в музичній освіті» (особистий сайт Л. Гаврілової, режим доступу: http://multimusic.com.ua/index.php/ua/), a також шляхом електронного листування й спілкування у чаті на сайті дистанційного навчання ДДПУ (http://ddpu.edu.ua:9090/moodle/), де розроблений і впроваджений у практику професійної підготовки майбутніх учителів музики курс «Історія української музики».

Дотримання принципу цілеспрямованої взаємодії i художньо-творчого спілкування педагога зі студентами у процесі формування професійної компетентності майбутніх учителів музики засобами мультимедійних технологій в умовах утворення нового інформаційно-комунікаційного педагогічного середовища дозволяє засвідчити перехід до трисуб'єктної дидактики, яка у сучасній науці (Л. Петухова, О. Співаковський, В. Коткова [12]) тлумачиться як один із напрямів педагогічної науки, що забезпечує свідоме і міцне засвоєння системи знань, умінь і навичок у межах рівноправних взаємин учня (студента), учителя (викладача) та інформаційнокомунікаційного педагогічного середовища.

\section{6. Принцип активізації музично-творчої діяльності, спонукання до творчого самовираження}

Принцип відбиває ще одну ключову закономірність музичного навчання забезпечення музичного розвитку активним включенням до музично-творчої діяльності [7]. Він спонукає до залучення різних форм музичної діяльності, до активізації творчих проявів майбутніх учителів музики, він спрямовує навчальну діяльність студентів на якомога глибше пізнання музики.

Засоби мультимедія, які наразі використовуються у системі формування професійної компетентності майбутніх учителів музики, активізують творчі прояви як в аудиторній, так і у самостійній роботі студентів. Опанування нескладних програм для підготовки мультимедійних презентацій (PowerPoint, ProShow Producer, Kingsoft Presentation Free та ін.), програм для створення й опрацювання відеороликів, слайдшоу, додавання титрів тощо (Windows Movie Maker, Movavi Video Suite та ін.), видання рекламної продукції, створення веб-вузлів (Microsoft Publisher) відкривають широкий простір для творчості із залученням мультимедійного контенту, зокрема у вивченні музично-історичних дисциплін. Попри це, мультимедійні технології надають можливість створювати музику на комп'ютері, що становить окрему галузь музичної діяльності (комп'ютерна музика, музично-комп'ютерні технології). 
Дотримання принципу активізації музично-творчої діяльності, спонукання до творчого самовираження в умовах залучення технологій мультимедія знаходиться в межах основних закономірностей мистецької, зокрема музичної, освіти. Як влучно зазначає Г. Падалка, активізація навчання передбачає пробудження художньої ініціативи, створення психологічного настрою на діяльність, досягнення стану мобілізації енергетичних сил учнів для здійснення художньо-творчих завдань [3, c. 175].

\section{4. ВИСНОВКИ ТА ПЕРСПЕКТИВИ ПОДАЛЬШИХ ДОСЛІДЖЕНЬ}

Отже, практична реалізація системи формування професійної компетентності майбутніх учителів музики засобами мультимедійних технологій вимагає дотримання таких принципів музично-педагогічної освіти:

- принципу інформатизації навчання, який забезпечує підвищення якості професійної музично-педагогічної освіти на основі використання новітніх інформаційно-комунікаційних технологій, створює умови інтенсифікації навчального процесу й утворення у навчальному закладі інформаційнокомунікаційного педагогічного середовища;

- принципу наочності, реалізованого засобами мультимедія, які характеризуються комплексною дією на відчуття людини і мають значно більший вплив на користувачів, ніж традиційні засоби наочності;

- принципу оптимального вибору засобів навчання, дотримання якого спонукало до аналізу існуючих електронних освітніх ресурсів, відбору серед них найдоцільніших для використання у професійній підготовці вчителів музики, а також призвело до створення власних мультимедійних навчальних засобів 3 музичного мистецтва;

- принципу інтеграції традиційних методик музичного навчання й інноваційних мультимедійних технологій, що передбачає розробку нових методів і форм музичного навчання на основі комп'ютерних, зокрема мультимедійних, технологій при збереженні широко апробованих, класичних методів навчання у викладанні професійно зорієнтованих дисциплін;

- принципу цілеспрямованої взаємодії і художньо-творчого спілкування педагога зі студентами, що орієнтує навчальний процес на забезпечення суб'єктсуб'єктного типу спілкування, розширення можливостей навчальної комунікації засобами дистанційного спілкування, демонструє на практиці нові форми трисуб'єктної взаємодії (студент - викладач - інформаційнокомунікаційне педагогічне середовище) і нові методи навчання;

- принципу активізації музично-творчої діяльності, спонукання до творчого самовираження, що спрямовує навчальну музично-педагогічну діяльність майбутніх учителів музики на творчі прояви 3 використанням засобів мультимедія.

Перспективи подальшого наукового пошуку вбачаємо у практичній реалізації розробленої системи, зокрема у різноаспектному застосуванні засобів мультимедія (як засобів навчання, як об' єктів вивчення й засобів діяльності) у професійній підготовці майбутніх учителів музики, а також у створенні нових мультимедійних навчальних засобів з музичного мистецтва для забезпечення потреб вищої музично-педагогічної освіти.

СПИСОК ВИКОРИСТАНИХ ДЖЕРЕЛ 
1. Кремень В. Г. Філософія: мислителі, ідеї, концепції : підручник / В. Г. Кремень, В. В. Ільїн. - К. : Книга, 2005. - 528 с. [Електронний ресурс]. - Режим доступу : http://studentbooks.com.ua/content/view/1396/53/1/0/.

2. Зайченко I. В. Педагогіка : навчальний посібник для студентів вищих педагогічних навч. закладів, 2-е вид. / І. В. Зайченко. - К. : Освіта України, КНТ, 2008. - 528 с.

3. Падалка Г. М. Педагогіка мистецтва (Теорія і методика викладання мистецьких дисциплін) : [монографія] / Галина Микитівна Падалка. — К. : Освіта України, 2008. — 274 с.

4. Абдуллин Э. Б. Теория музыкального образования : учеб. для студ. высш. пед. учеб. заведений / Э. Б. Абдуллин, Е. В. Николаева. - М. : Академия, 2004. - 333 с.

5. Музыкальное искусство. Программа / О. В. Усачёва, Л. В. Школяр, В. А. Школяр // Программнометодические материалы. Музыка. Начальная школа / сост. Е. О. Яременко. — М., 2001. — 256 с.

6. Алиев Ю. Б. Дидактика и методика школьного музыкального образования [Текст] / Ю. Б. Алиев. - М. : Изд-во Современного гуманитарного ун-та, 2010. - 340 с.

7. Ростовський О. Я. Теорія і методика музичної освіти : навч.-метод. посібник / О. Я. Ростовський. — Тернопіль : Навчальна книга - Богдан, 2011. - 640 с.

8. Андреев А. Электронная педагогика: может она и существует [Электронный ресурс]. — Режим доступа : : http://www.e-learning.by/Article/Elektronnaja-pedagogika-mozhet-ona-isuschestvuet/ELearning.html.

9. Петухова Л. С. Розширення можливостей навчального процесу в умовах інформаційнокомунікаційного педагогічного середовища / Л. Є. Петухова // Інформаційні технології в освіті. 2010. — № 6. - С. 32-37.

10. Олексюк О. М. Музична педагогіка : навчальний посібник / О. М. Олексюк. — К. : Київ. ун-т ім. Б. Грінченка, 2013. - 248 с.

11. Бойко Ю. І. Мультимедіа як інструмент невербального навчання / Ю. І. Бойко [Електронний peсурс]. - Режим доступу : http://int-konf.org/konf042013/206-boyko-yu-multimeda-yak-nstrumentneverbalnogo-navchannya-na-zanyatt-z-nozemnoyi-movi.html.

12. Співаковський О. В. Філософія трисуб'єктної дидактики в системі підготовки майбутнього вчителя початкових класів / О. В. Співаковський, Л. Є. Петухова, В. В. Коткова // Комп’ютер у школі та сім'ї. - 2014. - № 3. - С. 7-11.

Матеріал надійшов до редакиії 15.03.2015 p.

\title{
ПРИНЦИПЫ ФОРМИРОВАНИЯ ПРОФЕССИОНАЛЬНОЙ КОМПЕТЕНТНОСТИ БУДУЩИХ УЧИТЕЛЕЙ МУЗЫКИ СРЕДСТВАМИ МУЛЬТИМЕДИЙНЫХ ТЕХНОЛОГИЙ
}

\section{Гаврилова Людмила Гавриловна}

кандидат искусствоведения, доцент, докторант

Институт информатики НПУ имени М. Драгоманова, г. Киев, Украина

lusjamuz@mail.ru

\begin{abstract}
Аннотация. Статья посвящена актуальной проблеме современного высшего художественного образования - использованию компьютерных, в частности мультимедийных, средств обучения в процессе профессиональной подготовки будущих учителей музыки. Автор рассматривает принципы формирования профессиональной компетентности будущих учителей музыки средствами мультимедийных технологий: принцип информатизации обучения; принцип наглядности, реализованный средствами мультимедиа; принцип оптимального выбора средств обучения; принцип интеграции традиционных методик музыкального обучения и инновационных мультимедийных технологий; принцип целенаправленного взаимодействия и художественно-творческого общения педагога со студентами; принцип активизации музыкально-творческой деятельности, побуждения к творческому самовыражению. Соблюдение этих принципов обеспечивает эффективное профессиональное развитие будущих учителей музыки средствами мультимедийных технологий.
\end{abstract}

Ключевые слова: профессиональная компетентность; мультимедийные технологии; будущие учителя музыки; принципы обучения. 


\title{
PRINCIPLES OF MUSIC TEACHERS PROFESSIONAL COMPETENCE FORMATION BY MEANS OF MULTIMEDIA TECHNOLOGIES
}

\author{
Liudmyla H. Havrilova \\ Ph.D.in Art History, assistant professor, Doctoral student in Computer Engineering Department \\ National Pedagogical Dragomanov University, Kyiv, Ukraine \\ lusjamuz@mail.ru
}

\begin{abstract}
The article focuses on an urgent problem of contemporary artistic education and concerns implementation of multimedia computer aids of learning in the process of music teachers training. The author considers the principles of music teachers professional competence formation using multimedia technologies and defines them as follows: principle of informatization of learning; principle of visualization, supported with multimedia aids; principle of optimal selection of learning aids; principle of integration of traditional approaches to music education with innovative multimedia technologies; principle of purposeful interaction and creative cooperation between teacher and students; principle of promotion creative musical activities and personal selfexpression. Adherence to these principles determines effective professional development of music teachers through the means of multimedia technologies.
\end{abstract}

Keywords: professional competence; multimedia technologies; music teaching students; principles of education.

\section{REFERENCES (TRANSLATED AND TRANSLITERATED)}

1. Kremen V. H. Philosophy: thinkers, ideas, concepts: Tutorial [online] / V. H. Kremen, V. V. Ilin. - Kyiv : Kniga, 2005. - 528 p. — Available from : http://studentbooks.com.ua/content/view/1396/53/1/0/. (in Ukrainian).

2. Zaichenko I. V. Pedagogy: Textbook for students of higher educational institutions / I. V. Zaichenko. Kyiv : Osvita Ukrainy, KNT, 2008. — 528 p. (in Ukrainian).

3. Padalka H. M. Pedagogics of Art (Theory and methods of teaching artistic disciplines): [monograph] / H. M. Padalka. — Kyiv : Osvita Ukrainy, 2008. — 274 p. (in Ukrainian).

4. Abdullin Je. B. Theory of music education: a textbook for students of higher educational institutions / Je. B. Abdullin, E. V. Nikolaeva. - Moscow : Akademija, 2004. - 333 p. (in Russian).

5. The art of music. The program / O. V. Usachjova, L. V. Shkoljar, V. A. Shkoljar // Software and training materials. Music. Primary School / edited by E. O. Jaremenko. — Moscow, 2001. — 256 p. (in Russian).

6. Aliev Ju. B. Didactics and methodology of school music education [Text] / Ju. B. Aliev. — Moscow : Izd-vo Sovremennogo gumanitarnogo un-ta, 2010. — 340 p. (in Russian).

7. Rostovskyi O. Ya. Theory and methods of music education: teaching guide / O. Ya. Rostovskyi. Ternopil : Navchalna knyha - Bohdan, 2011. — 640 p. (in Ukrainian).

8. Andreev A. E-Pedagogy: can it exists [online]. - Available from : http://www.elearning.by/Article/Elektronnaja-pedagogika-mozhet-ona-i-suschestvuet/ELearning.html. (in Russian).

9. Petukhova L. Ye. Extending the learning process in terms of information and communication educational environment / L. Ye. Petukhova // Informatsiini tekhnolohii v osviti. — 2010. — № 6. — P. 32-37. (in Ukrainian).

10. Oleksiuk O. M. Music Teaching: Tutorial / O. M. Oleksiuk. - Kyiv : Kyjivsjkyj universytet im. B. Hrinchenka, 2013. - 248 p. (in Ukrainian).

11. Bojko Ju. I. Multimedia as nonverbal learning tool [online] / Ju. I. Bojko. — Available from : http://intkonf.org/konf042013/206-boyko-yu-multimeda-yak-nstrument-neverbalnogo-navchannya-na-zanyatt-znozemnoyi-movi.html. (in Ukrainian).

12. Spivakovsjkyj O. V. Philosophy trysub'yektnoyi didactics in training of Primary School Teacher / O. V. Spivakovsjkyj, L. Je. Petukhova, V. V. Kotkova // Komp'juter u shkoli ta sim'ji. — 2014. — № 3. - P. 7-11. (in Ukrainian). 